\title{
Reinventing Administrative Prescriptions: Spirituality in China?
}

\author{
LOOSEE BEH
}

\begin{abstract}
The decade of experience following the $9 / 11$ incident suggests a complex process of international development with a particular resurgence of interest in religiosity and spirituality. This paper attempts to explore the situation of spirituality in China. Several casesof moral degeneration on the part of public administrators and a silent crisis in governance can be related to the spirituality/non-spirituality factor and this situation suggests that China's leaders may do well to reinvent their country's public administration by working on elements of spirituality as they proceed with the process of market reforms, though this may be a lengthy struggle.
\end{abstract}

Keywords: China, religiosity, spirituality, governance, administration.

\section{Introduction}

A growing body of evidence demonstrates that spirituality produces a subtle but pervasive influence on judgement and decision-making. There is also an ongoing debate over the way globalisation and intensified international interaction are leading to a restructuring of administrative practices in order to achieve greater coherence and efficiency. Taken together these two strands of enquiry could suggest that spirituality can be used to off-set threats of institutional instability promoted by weakened multilateral institutions, the accelerated rate of globalisation and the rise of transnational issues that are too large to be managed by individual nation-states.

I have divided my paper into three sections. In the first I offer a discussion of aspects of the role of religion in China and in the second I discuss professionalism, spirituality and governance. In the third and last section of my paper I briefly outline a number of administrative issues and circumstances that point to a silent crisis in national governance. 


\section{The religious situation in China}

The concepts of religion and spirituality can be seen to be distinct. As Ashforth and Pratt (2003) state, 'the locus of spirituality resides in the individual'. By way of contrast, religion is typically regarded as more extrinsically focused, calling attention to institutional beliefs and practices and affiliation with an identifiable group (Berry 2005; Marler and Hadaway 2002; Pargament 1999). Religion is a set of principles, values, and doctrines that provide an ethical and moral framework for understanding, motivation, and behaviour (King, 2000). Spirituality may be more acceptable than religion due to its personal and individual nature though both influence the public and private lives of individuals. It has been argued that spirituality is particularly important and that cultivating a supportive and accommodating environment brings benefits to organisations. According to theories of public service motivation, public employees are expected to be committed to the public good and characterised by an ethic that is built on benevolence, life in the service of others and a desire to affect the community (Houston 2006). Religiosity and particularly spirituality may well strengthen standards of public administration and official behaviour and so strengthen national governance.

The Chinese word for 'religion' zongjiao itself denotes 'ancestral teaching', reflecting the Chinese emphasis on a collective relationship with the past rather than an individual's faith in a supernatural being. Popular religion has always been dismissed as superstition, particularly by Marxists. For the sociologist Emile Durkheim, religion persists because it offers symbolic expression of the loyalty felt by all individuals to the social group that enfolds and sustains their lives. Marxist theorists drew on similar conclusion, but argued that religion is a false form of consciousness. Today, China's largely apolitical populace has demonstrated that they are likely go along with the suppression of religiosity. They do this in the name of social stability. This situation brings us to the question - Is there freedom to profess religion in China and to what extent is religion practiced and tolerated by the government? It is difficult to answer this question. It may be more appropriate to argue that Chinese citizens function within the realm of patriotism. After the Cultural Revolution, religions have existed within the context of patriotism and atheism; and all other religious activities were looked upon as threats, feudalistic and superstitious. Perhaps the best word that describes the government policy on religion is pragmatism 
(Ariarajah 1986). It also has to be recognized that religion cannot be removed by force.

The widespread impression of China is that it is continuing to leap forward at least in terms of economic growth. The Chinese Communist Party maintains a monopoly of power and yet no political reform is evident. Spirituality or values of traditional Chinese culture have inclined to the ideology of Mao Zedong with many scholars pointing to the consistency and continuity of Confucianism and Chinese Communist ideology after the founding of the People's Republic of China (Pye 1985).

In traditional China people believed that all power emanated from above and centre resulting in a single supreme ruler. Careful research has shown that by the Shang period (1766-1123 B.C.) the term Shangdi (Lord on High) or Di (Lord) was already in use to refer to the highest of the gods, perhaps even to a creator god. In the Chou period (1122-249 B.C.), the term most often used for God was Tian (Heaven), symbolised by a large human head. After the Chou conquered the Shang, both $D i$ and Tian were used to refer to God, which was understood as a personal God. During the Han dynasty (206 B.C. - 220 C.E.), yin-yang thinking began to be absorbed into both Confucianism and Taoism. Although a reading of Taoist material might give one the impression that it claims that Ultimate Reality is somehow a combination of opposites, yin and yang, dark and light, good and evil, such a reading would indeed be superficial as in the Daode Jing (Tao Te Ching) itself, the $\mathrm{Dao}(\mathrm{Tao})$ is prior to heaven and earth - i.e., before duality (see Swidler and Mojzes, 2000). Dong Zhongshu (180-115 B.C), an eminent Confucian scholar during the Han dynasty, suggested that the emperor was the son of heaven because he had the mandate of heaven, and proposed that Confucianism became the ruling orthodoxy. Emperor Wu (156 - 87 B.C.) of the Han dynasty adopted Dong's proposal and promoted Confucianism, thereby entrusting the dominance for the next two thousand years.

Confucianism promoted the view that man is naturally good and is guided by morality which is more effective than just rule of law. Thus ideally the leader has authority due to his moral position and citizens would follow the example of the ruler. Throughout the Maoist years and to a lesser extent during the reform period, virtue was defined in terms of Communist ideals. Where necessary, 'sacrificing one's own life to complete one's virtue' and 'giving up life to attain righteousness' are considered natural by both Confucian and Communist ideology. For the past two thousand years, governance has hinged entirely on the 
moral quality of the rulers and officials (Guo 2006). However, as the country moved toward modernisation, Confucianism lost much of its influence (Hu 2007).

With Maoism and then Modernisation and institutionalised attempts to remove religion, the government's policy has been to operate a 'united' Chinese front committed to the good of the nation. This national good resides within the broad concepts of patriotism, mutual respect, and socialism. The government's policy towards religion was clear during the agony of the Cultural Revolution. Today, there are 40 million Communist Party members in a population of about one billion, and the percentage of the population that actually follows religion is rather small. It is therefore deemed that religious communities no longer pose a threat to social order. Nevertheless, there are ethnic communities in China for whom religion and ethnic identity are inseparable. These include Muslims and Tibetans where repression of religion has been associated with oppression. Indeed, attacks on Buddhist monasteries and temples during the Cultural Revolution amounted to an attempt to efface the cultural heritage of China itself (Ariarajah 1986).

The Chinese government has persecuted many new religious and spiritual groups, including Falun Gong, though they deny that this is the case. Falun Gong appears to be the most serious threat to the government and was banned in 2000. It was said to be a cult. Many analysts believe that Communist Party officials see the movement as a political threat. They recognize that nationalistic uprisings in Chinese history were spurred by similar folk religious movements.

There is no doubt that to a certain extent religious freedom exists in China today. To begin with, religions are expected to function in a patriotic way, which obliges them to approve if not actually support the present social, political, and economic order. In any case, no room is allowed for religious communities to engage in any sort of criticism of the present order. The government makes it clear that fundamentally, religious communities are solely concerned with spiritual affairs and function using a self-supporting, self-governing, and self-propagation system without serious external collaboration and more importantly assume no role in political matters. The authority of the People's Republic of China keeps on affirming their socialist standpoint, though not without certain criticisms of the Marxist orthodoxy. It is the reaffirmation of the orthodox Marxist ideal of religion which was repeated by Mao Zedong when he insisted that religious idealism and the dialectic materialism of the CCP were contradictory. Only Mao Zedong's Little 
Red Book of quotations was allowed and other religious texts such as the Bible and the Koran were effectively banned. China still prohibits the sale of Bibles through regular book shops despite the irony of manufacturing the text and being a leading exporter of Bibles.

New attempts are now being made to understand the role of religion in Chinese society and tolerance is exhibited in matters such as the establishment of the Institute for the Study of World Religions in Beijing. Another interesting point is that on 15 March 1979 under Mao's successor Deng Xiaoping, the Chinese Government issued its official policy on religion through the Bureau of Religious Affairs. This policy decreed that every citizen is free to believe, or disbelieve in any religion that one chooses. All religions are equal in the eyes of the authority and the political status of believers and non-believers with their own organisations is recognised. This policy also saw the re-establishment of the five main religions - Buddhism, Islam, Taoism, Catholicism, and Protestantism (Phongphit 1986).

There seems to be an apparent lack of interest in religion in China today (Pas 1989). This situation is demonstrated in two surveys conducted in 1995 and 2005. The surveys covered the cities of Nantong, Baoding, Beijing, Shanghai, Wuhan, and Guangzhou, and Beijing, Benxi, Qufu, Suzhou, Changsha, and Danjiangkou. The surveys revealed that more than 83 percent of the citizens in these cities were non-religious and atheists and in 2000 only 5.3 percent admitted to being religious. In 1995 the figure had been 2 percent. In 2005, the majority of urban Chinese claimed to be non-religious (51.8 percent) and atheists (32.9 percent).

In February 2007, a new government-sponsored survey on spirituality in China estimated that the number of religious believers is far higher than usually recognized amounting to as many as 300 million. The findings, based on a poll of 4,500 people conducted by East China Normal University in Shanghai, supported growing indications that many Chinese are searching for new value systems to replace the Communist doctrine that has been jettisoned in favour of market economics (Washington Post Foreign Service, 8 February 2007). The poll found a remarkable surge in religious belief that suggests a surge in moral inspiration that has not been reflected in the official estimates. This finding seemed to be of interest to Chinese leaders as they have sought to rebuild confidence in a Party apparatus often compromised by corruption and distance from the commoners. Historical Chinese religions such as Buddhism, Taoism, and Islam accounted for 67 percent of those who declared themselves believers. Officially sanctioned Christian 
organisations have said 15 million Protestants and 6 million Catholics participate in their religious practices in China. However, Chinese and foreign researchers estimate that the figure could be higher due to the semi-secrecy which makes an accurate count impossible. The main factor in the fast growth of religion is not attributed to just population growth but to an expanded freedom of belief in China. During the 1960s and 1970s radical political orthodoxy enforced by Mao Zedong and his followers replaced religious beliefs, often under threat of imprisonment. Although the Communist Party remains officially atheist, Chinese are now free to practice the religion of their choice to an extent that it does not challenge the party's monopoly on power.

\section{Professionalism, Spirituality, and Governance}

Most problems related to administrative professionalism revolve around the control of knowledge and expertise. Confucianism and Maoism have exercised control over information and so have prevented and undermined the manifestation of democratic values. As the social and political theorist Zygmunt Bauman (1986) has noted, 'The communist revolution explicitly proclaimed and ostensibly practiced the unity of power and knowledge, the innermost core of the intellectual idiom.' Hence, one need scarcely look further than the slogans 'The party knows best' and 'The party is always right' to posit alternative values.

If spiritual affirmation is not tied to real political values and directions, what good is the expression of such public piety? And how could genuine discussion of moral, spiritual, or religious values in public life contribute to the formation of much needed reformed political options? Ultimately, it should concern the representation of public reason. Chantal Mouffe (1993) takes politics as 'the set of practices and institutions through which an order is created, organizing human coexistence in the context of conflictuality provided by the political' and refers to the agonistic struggle for hegemony. The political refers to the potential emergence of antagonism. Mouffe argues that every society is the product of a series of practices attempting to establish order in a context of contingency and refers to the struggle for hegemony as 'agonism': the symbolic context over the constitution of society, the institution of an order in which a potentially inter-communal conflict (war) is represented as communal (politics). Mouffe has appropriated the notion of hegemony from Antonio Gramsci (Schaap 2007). In Arendt's major works, the political refers to the potential experience of 
solidarity in moments of collective action. According to Arendt, politics is public. It is possible only where there is a public space within which men and women can appear before each other. Politics arises out of the plurality of perspectives that individuals bring to bear on the world. The above briefly outlined arguments and definitions provide a solid basis for discussing modern Chinese politics. It is in the context of China's present political landscape that I am canvassing the potential for spirituality that, in turn, may address the moral degeneration that has been identified among public administrators and an attendant silent crisis in governance.

The dichotomy of profit and righteousness remain entrenched in Confucian tradition. However, Deng Xiaoping popularised the function of profit-seeking at the beginning of the process of economic reforms. The reforms initiated by Deng Xiaoping have undermined the Communist ideology, changed China's socioeconomic system, and increased China's international status.

Independent of their adherence to religion, most Chinese are struggling with what spirituality means for their work and family. If there is spirituality, then why is it solely for the purpose of stating loyalty to the party and state? Is religion such a threat to the CCP's power, authority, and legitimacy? Religions which are not state-sanctioned are often portrayed as part of separatist movements and no one under the age of 18 is allowed to practice any religion. At the same time the fear of the relationship between pro-democracy movements, underground churches and external influences is used to justify repression.

Before the 1949 Communist ascendancy over China, most Chinese seemed to be politically apathetic and ignorant. Between the 1950s and the 1970s, the CCP launched a series of mass political movements that led to a Chinese populace who exhibited significant enthusiasm in relation to public and political affairs. During the years of the Cultural Revolution (1966-76), almost all the citizens were concerned and participated in politics. Since reforms were first implemented the Chinese have been perceived to be obsessed about money-making and material goods with no interest in public affairs.

Anti-Confucianism peaked during the Cultural Revolution so much so that Mao launched the Anti-Confucius campaign. However, the state's attitude towards Confucianism softened in the later years of the Cultural Revolution and in the aftermath of 1989 democratic movement Deng Xiaoping reintroduced the civil service examination, a traditional Confucian concept that seems to pick up again under $\mathrm{Hu}$ 
Jintao's tenure (Hu 2007). President $\mathrm{Hu}$ Jintao is generally considered to have been selected by Deng Xiaoping to succeed Jiang Zemin. The history of the Communist Party's leadership is not just one of leaders but, more importantly, of their ideologies: Mao Zedong Thought, Deng Xiaoping Theory, Jiang Zemin's 'Three Represents' and now Hu Jintao's 'Harmonious Socialist Society.' Each leader's ideology combines their own novel formulations with particular elements strategically selected from previous leaders' guiding thoughts, in turn reinventing the administrative prescriptions. This means that there is an overarching ideological continuity between leaders as well as their own particular programme being the logical consequence of that which had preceded it. These ideological frameworks necessarily adhere to some general Marxist concept of historical development leading to one ultimate destination which is Communism. This means that each leader's ideology necessarily addresses two issues: where China currently is on the path and how China can best progress along the path (Herschler 2007). It is thought that this model is based not only on continued economic growth but also on fair distribution of the growth unlike the unrestrained and unbalanced growth of the Deng Xiaoping and Jiang Zemin eras.

Building a 'harmonious socialist society' is presented as a natural consequence of the Party's success in upholding reforms. These include the legal system, economic disparities, employment, morality and culture, creativity and innovation, public administration and environmental actions. It is clear that the central government is to play a decisive role in dispelling contradictions through a range of national policy endeavours and scholars are tempted to conclude that $\mathrm{Hu}$ is taking a more Socialist path. In this economically dynamic and politically intriguing nation, much of Hu's political demeanour seems to suggest a Confucian style of leadership, one who governs by virtuous example, but old Maoist structures remain with traditional-sounding rhetoric about harmony and peace. Hu advocates the principle of Confucianism where the interests of rulers and people are closely related and mutually beneficial, while the majority of the leaders share the Leninist veneration for authority and orthodoxy.

Many problems facing China today, such as inequality, immorality, insecurity, alienation, rootlessness and ruthlessness can be linked to the relentless pursuit of efficiency and the neglect of human problems by leaders whose training is limited to science and engineering. Technocracy has taken root in China's economic and political system since the 1980s. It is an important step towards acquiring what Max Weber termed 
a rational-legal basis of political legitimacy. However, the lack of popular sovereignty and innate tendency toward oligarchic rule will eventually weaken the legitimacy of bureaucratic technocracy (Guo 2007).

In this paper I argue that a silent crisis in governance may well exist in the People's Republic of China. In describing state-society relations, government is always the head, the thinking part of the body. One of the important tests of good governance is to measure how well governmental institutions identify critical issues and choices facing society now and in the future. This is apparently difficult as China remains indelibly communist while avoiding any unsettling political reforms, much less a democratic path. The identification of societal problems is therefore not distinguishable from proposing solution.

It is in the above context that the Tibetan's struggle to regain and maintain their civilisation against enormous odds is continuing. Reproaching the China authorities can result in arrests and imprisonment that are often made on the basis of state surveillance. China's notion of Tibetan Buddhism as the backbone of Tibetan resistance to assimilation and the insistence that Tibetans yield to China's authority, has culminated in recent crisis of civil disturbances in the first quarter of 2008. At the same time, and all too readily, the Tibetans have become accustomed to being portrayed as victims. It is difficult to envisage the possibility of autonomy for Tibet. Observers constantly point to conflict though the Dalai Lama demonstrates the profound importance of religion in the tolerance and resolution of conflict. A similar situation also arose in the Soviet Union where Stalin's policies caused the unjust deaths of thousands of people, destroyed Buryat Buddhist culture and split the Buryat into separate administrative units amid hysterical accusations of Pan-Mongolism to enforce loyalty to Russia. Widespread armed uprisings against collectivisation in 1929-32 in the south, east, and west of Buryat lands hailed the freedom of worship. It was not just a matter of peasant resentment of forced egalitarianism of the collectives but also for ideological and political concerns in opposition to Communism. By 1938, virtually all Buddhist lamas and activists perished. On the other hand, knowledge of such matters is thrust inward and hidden and people lived their lives through Marxism-Stalinism. However,the outrage of the people against guandao at the time of the Tiananmen Incident in 1989 was not hidden. It taught officals a lesson. After the Tiananmen Incident, with the exception of certain areas of Guangdong and Shandong provinces, reform and liberalisation stagnated nationwide. The Chinese Communist Party found that they must be firm in their dealings with corruption. If they followed this 
path in combination with the economic leadership of Zhu Rongji, there would be the possibility of comparatively stable development of China's politics and economics. Corruption is an inevitable weakness of a Communist Party dictatorship, indeed of any single-party dictatorship, due to the absence of checks and balances on power to effectively control it.

The next issue of considerable concern for both China's leaders and Chinese citizens relates to the effective implementation of public policy. The cost of government failure is rarely identified and publicised and this is the case not only in China but in many other countries as well. Implementation studies have generally emphasised the gap between what is intended and what is actually achieved. Obviously governments that lack the ability to implement policy with some degree of effectiveness are wasting the resources, time and effort of those who make public policy. While there is no doubt that much is achieved by government on a regular basis, several developments suggest a reduced capacity of government to engage effectively in policy implementation and this is something that could be attributed to a lack of spirituality and religiosity among government administrators. Public human resource management has served many masters in China. China's leaders have depended on both ancient wisdom and communist doctrine as guides to action. Now, new guides may well be needed.

Paternalism results in government organs overseeing subordinate administrations to the degree that they stifle the ability to make operational decisions and destroy their incentives to cut costs and meet market needs. This applies particularly to those enterprises that continue to be state run. It also means that inefficient practices and enterprises are protected. In the past state-owned enterprises have been put in a position where they 'bear responsibility for profits but not for losses'. For those enterprises that continue under direct government administration this situation continues. It has been recognised that unless reform measures are coordinated with each other and implemented with an overall design, their effectiveness will be diminished and it will be difficult to control the results of reform.

In post-reform China the shortage of energy resources has been exacerbated by the economic consequences of the administrative and fiscal decentralisation that took place under the umbrella of economic reform. Given the irrational aspects of price and taxation and other fiscal incentives, localities have had incentive to invest in processing industries which have a shorter investment cycle and yield higher profits, thereby fuelling high-speed growth and exacerbating energy and supply shortages. 


\section{Administrative Issues}

Poor governance has costs that are less dramatic in the short term but are cumulative. In this paper I am arguing not only that poor governance is cumulative but that the governance crisis in China could be significant given the level of unethical decision-making and work procedures as experienced by many. The creation of effective governance capacity is a lengthy struggle and for that reason alone reform should be promoted. For all the rhetoric about market reform, the Chinese government continues to play a considerable role in the lives of many citizens. At the same time, the administration's response to corruption, which remains disturbingly prevalent, has often been slow and inadequate.

Religion has been widely credited with providing coherent morality systems among people and, maybe even more importantly, the lack of religion and/or spirituality among public administrators can be seen to have the capacity to weaken public decision-making to the point where bad governance is wide-spread. However, there are doubts raised in relation to this point of view and perhaps the strongest doubts over the wisdom of expanding the relationship between religion and public administration have been over the question of whether nurturing strong values founded on diverse theologies and cultures can actually create the kind of coherent values and national identity that modern societies are searching for. Given the secularisation of China and the much discussed views of social thinkers like Auguste Comte, Herbert Spencer, Emile Durkheim, Max Weber, Karl Marx and Sigmund Freud, religion could be expected to gradually fade in importance and cease to be significant with the advent of industrialisation, rationalisation, and urbanisation. However, on the other side of the ledger, there is no question that the traditional secularisation thesis needs updating. In relatively secure societies, remnants of religion have not died away and many developed societies associate themselves with a religion on official forms. In vulnerable societies especially those in poorer nations religiosity persists more strongly. The most persuasive evidence about secularisation concerns values and behaviour. The critical test is what people say is important to their lives and what they actually do. Many people who have business dealings seem to be sceptical over the work practices, inconsistencies, and values which are steadily diminishing in China. The indicators of religiosity seem to apply here though no empirically research on the issue is readily available. Evidence established through contacts admittedly may not be conclusive evidence, but it does provide interesting 'food for thought'. 
In China today, market-oriented reforms are widely blamed for moral degeneration. The reforms promoted by Deng Xiaoping have produced many money worshippers. Increased levels of selfishness and mistrust have accompanied the social transition from a centrally planned economy to a market economy. With the intensification of market-oriented reforms (particularly since the early 1990s), business and money-making have become even more important concerns. Citizens have also become indifferent to political struggles, ideology and movements (Guo 2006).

China's mounting domestic problems resulting from accelerated market reforms have caused deep concern among intellectuals. Corruption, crime, a floating population, unemployment, and income disparity have had a destabilising effect on the social order. Grave domestic concerns and uncertainties not only strengthened the position of those who consistently supported neo-authoritarian politics, but also many who previously favoured liberal democratic ideas. They have also been converted to neo-conservatism. Chinese political leaders appear to embrace authoritarianism at the first sign of crisis.

It is obvious that the majority of ordinary urban citizens support and trust the Chinese government policies and the CCP regime even though they clearly have a large number of concerns. Another case of concern is that the private firms are vulnerable to rent-seeking officials. Structural disadvantages have induced private firms to engage in intensive networking to cope with uncertainty and as a means of acquiring status. Networks are proactively cultivated with business contacts receiving ever more expensive and non-reciprocated gifts which in turn leads to intensive investment in networking (Chen 2007). It has even been argued that network ties with high-ranking officials are a valuable and rare resource that is difficult to imitate. This resource is a source of competitive advantage. Party affiliations and cadre status has become a form of capital - with the human, social, financial and political intertwined and mutually reinforcing one another (Chen 2007). This situation, that I believe could well be rooted in the lack of religiosity and spirituality among public servants, makes it necessary for the government to cultivate citizens of good character with a commitment to serve and promote the common good, even though the obligation to serve others need not be overtly religious.

Bribery-case convictions in China have been applauded, but more must be done. In 2007 China's anti-graft fight proved to be particularly fruitful with prominent figures like the former party chief of Shanghai, 
Chen Liangyu, being implicated in the misuse of the city's public social security fund. He was convicted. Some other high-ranking figures removed from their positions on corruption charges included Liu Zhihua, former vice-mayor of Beijing; Qiu Xiaohua, former head of the National Statistics Bureau; Zheng Xiaoyu, former head of China's State Food and Drug Administration; Cao Wenzhuang, former director of the same department and Hao Heping, former director of medical equipment of the State Food and Drug Administration. Corrupt practices by prominent figures undermine the implementation of policies and pose a significant threat to the public interest.

\section{Concluding note}

Recent Chinese government efforts to develop an ethic of public administration grounded in good governance are compatible with the nature of spirituality and, on a quite hopeful note, whilst China's market transition has been state-initiated, gradual and experimental, it can be pointed out that this approach could be copied with regard to the promotion of religiosity and spirituality. Currently, values such as individualism, nationalism, and capitalism appear to be more influential than religiosity and spirituality not only in China but also in other parts of the world, though we must recognise that there are notable exceptions to this rule.

As is the case elsewhere, Chinese public servants and leaders are obligated to serve as exemplars of spiritual virtues if not religiosity through their commitment to the common good, service to others and benevolent action and it is this obligation that provides a link between public service and spirituality. It seems fair to argue that China's leaders may well have an interest in reinventing public policy implementation by promoting elements of spirituality. It is a scenario that fits well with the Chinese ethos of pragmatism.

LooSee Beh is Senior Lecturer at Department of Administrative Studies And Politics, University of Malaya, Kuala Lumpur (lucybeh@um.edu.my).

\section{REFERENCES}

Arendt, H. 1998. The Human Condition. Chicago: University of Chicago Press.

Ariarajah, S.Wesley 1986. 'Religion in China: Some Impressions.' Inter-Religio 10: 5065. 
LooSee Beh

Ashforth, B.E. and M. G. Pratt 2003. 'Institutionalized Spirituality: An Oxymoron?' In R.A.Giacalone et al. (eds). Handbook of Workplace Spirituality and Organizational Performance. New York: M.E. Sharpe: 93-107.

Bauman, Z. 1987. 'Intellectuals in East-Central Europe: Continuity and Change.' Eastern European Politics and Societies 1: 162-86.

Berry, D. 2005. 'Methodological Pitfalls in the Study of Religiosity and Spirituality.' Western Journal of Nursing Research 27(5): 628-47.

Bruce, W. 2000. 'Spirituality in Public Service.' International Journal of Organizational Theory and Behavior 3 (3-4): 599-632.

Cahill, L. Sowle 1990. 'The New Testament and Ethics: Communities of Social Change.' Interpretation: A Journal of Bible and Theology 44(4):383-95.

Cavanagh, G. F. and M. R. Bandsuch 2002. 'Virtue as a Benchmark for Spirituality in Business.' Journal of Business Ethics 38(1-2):109-17.

Chen, W. 2007. 'Does the Colour of the Cat Matter? The Red Hat Strategy in China's Private Enterprises.' Management and Organization Review 3(1): 55-80.

Fewsmith, J. 1994. Dilemmas of Reform in China: Political Conflict and Economic Debate. New York \& London: M.E. Sharpe, Inc.

Garcia-Zamor, J. 2003. 'Workplace Spirituality and Organizational Performance.' Public Administration Review 63(3): 355-64.

Guo, D. 2006. 'Democratic Developments and Changing Values in China.' In T. Inoguchi et al. (eds). Governance and Democracy in Asia. Victoria: Trans Pacific Press 2006. 131-62.

Guo, B. 2007. 'The New Politics of Equity.' China Currents 6(2), 22-3.

Haughey, J. C. 1989. Converting Nine to Five: A Spirituality of Daily Work. New York: Crossroad.

Herschler, S. 2007. 'Can development dissolve swords and shields? Hu's 'Harmonious Socialist Society betwixt Mao Thought and Deng Theory.' China Currents 6(2), 8-11.

Hill, P. C. and G. S. Smith 2003. 'Coming to Terms with Workplace Spirituality and Religion in the Workplace.' In R.A.Giacalone et al. (eds). Handbook of Workplace Spirituality and Organizational Performance. New York: M.E.Sharpe. 231-43.

Houston, D. J. 2006. "'Walking the Walk" of Public Service Motivation: Public Employees and Charitable Gifts of Time, Blood, and Money.' Journal of Public Administration Research and Theory 16(1): 67-86.

Houston, D. J. and K. E. Cartwright 2007 'Spirituality and Public Service'. Public Administration Review Jan/Feb: 88-102.

Hu, S. 2007. 'Confucianism and Contemporary Chinese Politics'. Politics \& Policy 35(1): 136-53.

Johnson, A. L. 2007. 'Mary Parker Follett: Laying the Foundations for Spirituality in the Workplace'. International Journal of Public Administration 30: 425-439.

King, S. M. 2000. 'Toward a New Administrative Ethic: An Understanding and Application of the Judeo-Christian Tradition to Administrative Issues.' Public Integrity 2(1): $17-28$.

- 2007. 'Religion, spirituality and the workplace: Challenges for public administration.' Public Administration Review Jan/Feb: 103-14.

Koppell, J. G.S. 2007. 'Political Control for China's State-Owned Enterprises: Lessons from America's Experience with Hybrid Organizations.' Governance: An International Journal of Policy, Administration, and Institutions 20(2): 255-78.

Marler, P. Long, and C. Kirk Hadaway 2002. 'Being religious or Being Spiritual in America: A Zero-Sum Proposition.' Journal for the Scientific Study of Religion 41(2): 289-300. 
Mouffe, C. 1993. The Return of the Political. London: Verso.

Pas, J. (ed.) 1989. 'The Turning of the Tide - Religion in China Today.' Oxford: Oxford University Press.

Pargament, K. I. 1999. 'The Psychology of Religion and Spirituality? Yes and No.' International Journal for the Psychology of Religion 9(1): 3-16.

Phongphit, S. 1986. 'A New Dawn for Religion in China.' Inter-Religio 10: 66-78.

Pye, L. 1985. Asian Power and Politics: The Cultural Dimensions of Authority. Cambridge: Belknap Press.

Schaap, A. 2007. 'Political Theory and the Agony of Politics.' Political Studies Review 5: $56-74$.

Swidler, L. and P. Mojzes 2000. The Study of Religion in an Age of Global Dialogue. Philadelphia: Temple University Press.

Walton, C. C. 1988. The Moral Manager. New York: Ballinger.

Washington Post Foreign Service, 8 February 2007. Available from: http:/ /www.washingtonpost.com/wpdyn/content/article/2007/02/07AR2007020702069.html [accessed 24 December 2007]. 